\title{
Antitcoagulant and antiplatelet activities of scolymoside
}

\author{
Eun-Kyung Yoon ${ }^{1, \#}$, Sae-Kwang Ku ${ }^{2, \#}$, Wonhwa Lee ${ }^{1,3}$, Soyoung Kwak ${ }^{1}$, Hyejin Kang ${ }^{1}$, Byeongjin Jung ${ }^{1} \mathcal{E}_{\text {Jong-Sup Bae }}{ }^{1, *}$ \\ ${ }^{1}$ College of Pharmacy, CMRI, Research Institute of Pharmaceutical Sciences, Kyungpook National University, Daegu 41566, ${ }^{2}$ Department \\ of Anatomy and Histology, College of Korean Medicine, Daegu Haany University, Gyeongsan 38610, ${ }^{3}$ Department of Biochemistry and Cell \\ Biology, BK21 Plus KNU Biomedical Convergence Program, School of Medicine, Kyungpook National University, Daegu 41566, Korea
}

Cyclopia subternata is a medicinal plant commonly used in traditional medicine to relieve pain. Here, the anticoagulant effects of scolymoside, an active compound in C. subternata, were examined by monitoring activated partial thromboplastin time (aPTT), prothrombin time (PT), and the activities of thrombin and activated factor $X$ (FXa). The effects of scolymoside on plasminogen activator inhibitor type 1 (PAl-1) and tissue-type plasminogen activator (t-PA) expression were evaluated in tumor necrosis factor (TNF)- $\alpha$-activated human endothelial cells. Treatment with scolymoside resulted in prolonged aPTT and PT and the inhibition of thrombin and FXa activities and production. In addition, scolymoside inhibited thrombin-catalyzed fibrin polymerization and platelet aggregation. Scolymoside also elicited anticoagulant effects in mice, including a significant reduction in the PAl-1 to t-PA ratio. Collectively, these findings indicate that scolymoside possesses anticoagulant activities and could be developed as a novel anticoagulant. [BMB Reports 2015; 48(10): 577-582]

\section{INTRODUCTION}

Herbal teas are natural beverages containing biological active compounds that can promote health owing to their potential in vivo biological properties $(1,2)$. As an endemic South-African fynbos plant, Cyclopia subternata Vogel (Family: Fabaceae; Tribe: Podalrieae) has been used as an herbal tea called honeybush after "fermentation," a high-temperature oxidative process required to produce its characteristic sweet aroma and flavor (3). The health-promoting properties of the active compounds in C. subternata that have been documented include antioxidant and anti-inflammatory activity and the enhancement of recognition memory (4-6). It is known that abundant

*Corresponding author. Tel: +82-53-950-8570; Fax: +82-53-9508557; E-mail: baejs@knu.ac.kr

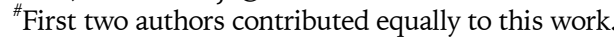

http://dx.doi.org/10.5483/BMBRep.2015.48.10.044

Received 4 March 2015, Revised 23 March 2015, Accepted 16 April 2015

Keywords: Coagulation cascade, Endothelium, Fibrinolysis, Scolymoside flavonoids are contained within C. subternata, particularly scolymoside (SCL) (7).

There exists a well-known relationship between diet and health; food contributes significantly to the maintenance of good health (8) and is regarded as functional health foods if they benefit several functions in nutritional effects (9). When consumed in adequate amounts on a consistent basis, functional health food could decrease the vascular inflammatory diseases such as cardiovascular diseases (CVDs) by reducing lipid levels, oxidation of low-density lipoprotein, formation of plaque, and platelet aggregation, or improving arterial compliance $(9,10)$. This fact has garnered great interest in the search for natural bioactive compounds that contribute to platelet inhibition. Interestingly, many natural bioactive compounds from functional foods have been reported to exhibit antiplatelet activity.

In addition to previous reports demonstrating the potential antioxidant effects of $\mathrm{SCL}$, we hypothesized that $\mathrm{SCL}$ may have anticoagulant activities. To date, it was not reported the effects of SCL on coagulation. Therefore, we investigated the anticoagulant and antiplatelet activities of SCL in terms of activated factor $\mathrm{X}(\mathrm{FXa})$ and thrombin production and its effects on prothrombin time (PT), activated partial thromboplastin time (aPTT), and fibrinolytic activity.

\section{RESULTS AND DISCUSSION}

SCL (SCL, luteolin-7-O-rutinoside) is a compound found in C. subternata plants, which are traditionally used for the production of the South African herbal tea honeybush, and recently their aqueous extracts have been used in the food industry (3). Here, we determined the anticoagulant and antiplatelet effects of SCL (Fig. 1A) and attempted to identify the mechanisms responsible for these effects.

\section{Effects of SCL on clotting and bleeding times}

The incubation of human plasma with $\mathrm{SCL}$ altered coagulation properties. The anticoagulant activities of SCL were tested with human plasma using aPTT and PT assays (Table 1). Although the anticoagulant activities of SCL were weaker than those of heparin and warfarin, aPTT and PT were significantly prolonged by SCL $(\geq 5 \mu \mathrm{M})$. Prolongation of aPTT suggests the inhibition of intrinsic and/or common pathway, and PT pro-

ISSN: 1976-670X (electronic edition)

Copyright (C) 2015 by the The Korean Society for Biochemistry and Molecular Biology

(c) This is an open-access article distributed under the terms of the Creative Commons Attribution Non-Commercial License (http://creativecommons.org/licenses/by-nc/4.0) which permits unrestricted non-commercial use, distribution, and reproduction in any medium, provided the original work is properly cited. 
Scolymoside (SCL); $\mathrm{R}_{1}, \mathrm{R}_{3}=\mathrm{H} ; \mathrm{R}_{2}=$ glucosyl; $\mathrm{R}_{4}=\mathrm{OH}$

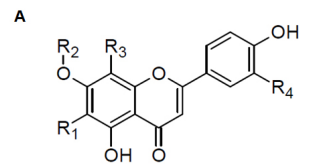

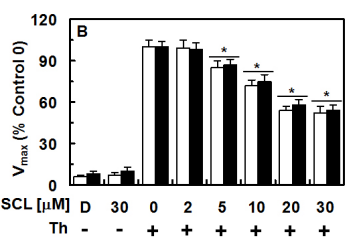

Th $-\begin{array}{ccccccc}30 & + & 2 & 5 & 10 & 20 & 30 \\ & & + & + & + & +\end{array}$

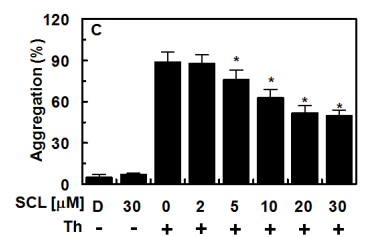

Fig. 1. Chemical structure of SCL and effects of SCL on cytotoxicity and fibrin polymerization in human plasma. (A) Structure of scolymoside (SCL). (B) Thrombin (Th, white box)- or reptilase (Rep, black box)-catalyzed fibrin polymerization at the indicated concentrations of SCL was monitored using a catalytic assay, as described in the "Materials and Methods" section. The results are $\mathrm{V}_{\max }$ values expressed as percentages versus controls. (C) Effect of $\mathrm{SCL}$ on mouse platelet aggregation induced by $3 \mathrm{U} / \mathrm{mL}$ thrombin. $\mathrm{D}=0.2 \%$ DMSO is the vehicle control. Data represent the mean \pm SEM of three independent experiments performed in triplicate. ${ }^{*} \mathrm{P}<0.05$ vs. Th alone $(\mathrm{B}, \mathrm{C})$ or reptilase (B). longation suggests the inhibition of extrinsic and/or common pathway. SCL treatment at $27.7 \mu \mathrm{M}$ and $24.8 \mu \mathrm{M}$ were required to double clotting time for aPTT and PT, respectively. Therefore, the results obtained in this study indicate that $\mathrm{SCL}$ could also inhibit the common coagulation pathway. To confirm these in vitro results, in vivo tail bleeding times were assessed. Because the average mouse body weight is $20 \mathrm{~g}$ and average blood volume is $2 \mathrm{~mL}$, administration of $11.9,23.8$, or $35.7 \mu \mathrm{g} \mathrm{SCL} /$ mouse produced concentrations of approximately 10,20 , or $30 \mu \mathrm{M}$ in peripheral blood, respectively. Data showed that in vivo bleeding times were prolonged significantly by $S C L$ in comparison to the controls (Table 1 ). We confirmed this data ex vivo aPTT and PT analysis dose dependent manner with SCL (Table 1).

Effects of SCL on fibrin polymerization and cellular viability Then, we tested the effects of SCL on thrombin-catalyzed fibrin polymerization in purified human plasma, as described in the Materials and Methods section. Fig. 1B shows that SCL significantly decreases the maximal rate of fibrin polymerization. $50 \mathrm{mM}$ TBS ( $\mathrm{pH}$ 7.4) and same volume of DMSO were used to exclude the possibility that $\mathrm{pH}$ and volume could affect the

Table 1. Anticoagulant activity of scolymoside ${ }^{a}$

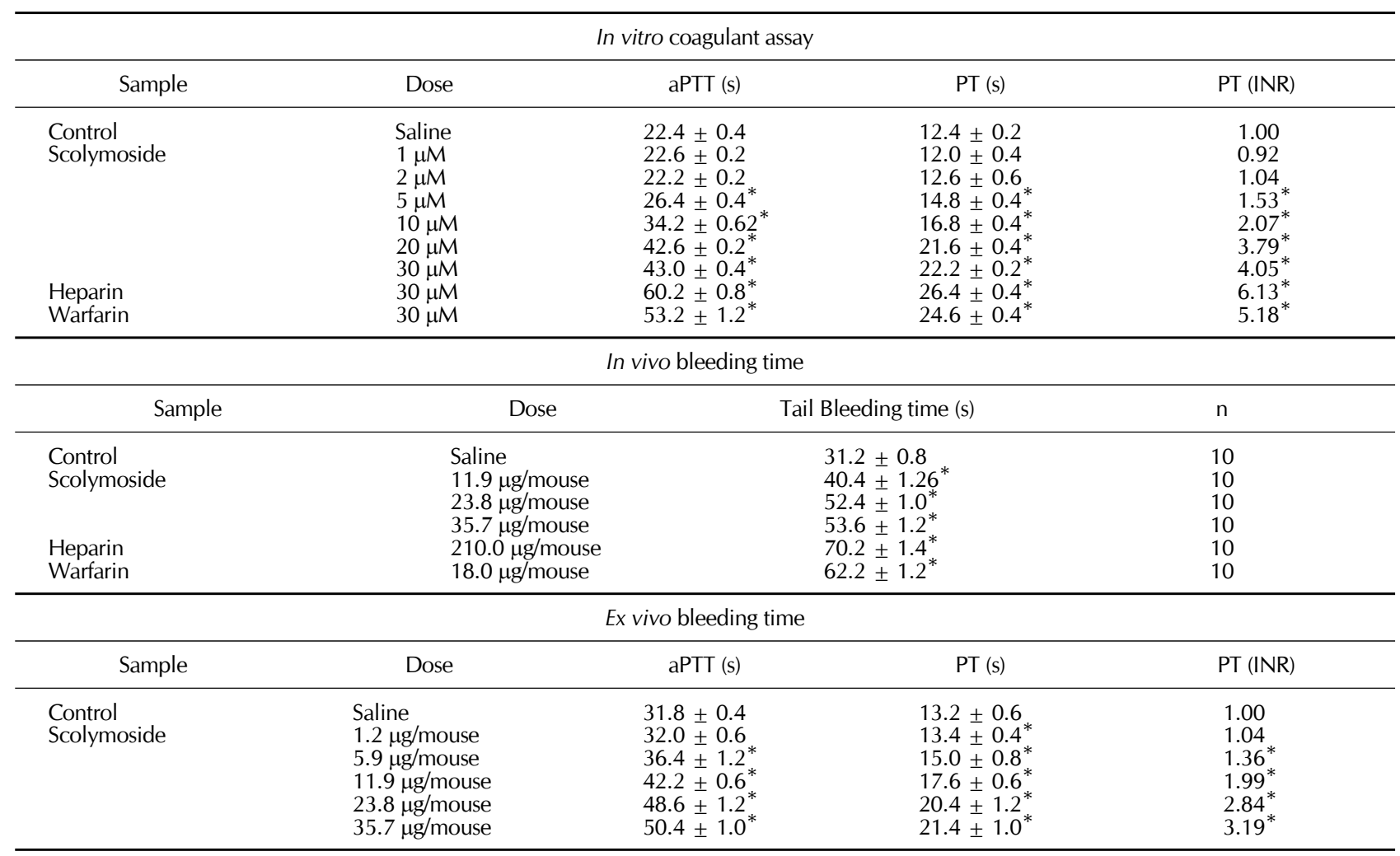

${ }^{\mathrm{a}}$ Each value represents the means $\pm \operatorname{SEM}(n=5)$.

$* \mathrm{P}<0.05$ as compared to control. 
obtained results, respectively. Data was not affected by two factors (data not shown). To eliminate the effects of thrombin on the reduction in fibrin production rather than the polymerization of formed fibrin, a reptilase was used to induce fibrin polymerization. Data show that reptilase-catalyzed fibrin polymerization was significantly decreased by SCL (Fig. 1B). To determine the effect of SCL on cellular viability, a cellular viability assay (MTT assay) was performed in human endothelial cells treated with SCL for $24 \mathrm{~h}$. SCL did not affect cell viability at concentrations up to $50 \mu \mathrm{M}$ (data not shown).

Effects of SCL on platelet aggregation catalyzed by thrombin To confirm the anticoagulant activities of SCL, a thrombin was used to catalyze the platelet aggregation. In washed murine platelets, SCL treatment $(0-30 \mu \mathrm{M})$ for 5 min inhibited the platelet aggregation induced by thrombin $(3 \mathrm{U} / \mathrm{mL})$ with an $\mathrm{IC}_{50}$ value of $29.4 \mu \mathrm{M}$ in a concentration-dependent manner. The 5 -min incubation period was chosen because an optimal inhibitory effect of SCL was observed at $5 \mathrm{~min}$.

\section{Effects of SCL on the activities of thrombin and FXa}

In order to determine the underlying mechanism of SCL-mediated inhibition of coagulation, we tested the effects of SCL on
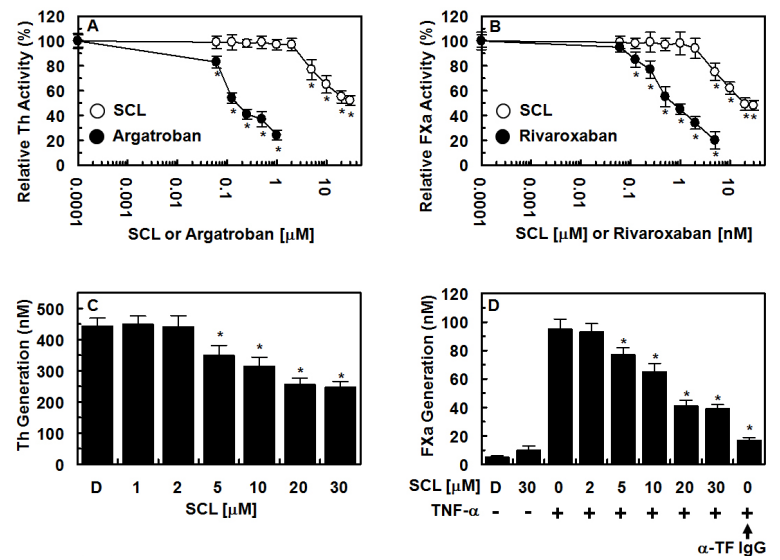

Fig. 2. Effects of SCL on the inactivation and production of thrombin and factor Xa. (A) Inhibition of thrombin (Th) by SCL was measured using a chromogenic assay, as described in the "Materials and Methods" section. (B) Inhibition of factor Xa (FXa) by SCL was monitored using a chromogenic assay, as described in the "Materials and Methods" section. Argatroban (A) or rivatoxaban (B) was used as positive control. (C) HUVECs monolayers were pre-incubated with FVa (100 pM) and FXa $(1 \mathrm{nM})$ for $10 \mathrm{~min}$ with the indicated concentrations of SCL. Prothrombin was added to a final concentration of $1 \mu \mathrm{M}$, and prothrombin activation was determined 30 min later, as described in the "Materials and Methods" section. (D) HUVECs were pre-incubated with the indicated concentrations of SCL for $10 \mathrm{~min}$. TNF- $\alpha$ (10 ng/mL for $6 \mathrm{~h}$ )-stimulated HUVECs were incubated with FVIla $(10 \mathrm{nM})$ and FX $(175 \mathrm{nM})$ in the absence or presence of anti-TF IgG $(25 \mu \mathrm{g} / \mathrm{mL})$, and FXa production was determined as described in the "Materials and Methods" section. ${ }^{*} \mathrm{P}<0.05$ vs. 0.0001 (A, B), D (C) or TNF- $\alpha$ alone (D). the activities of thrombin and FXa. Data showed that the activity of thrombin was inhibited by SCL treatment (Fig. 2A), suggesting the direct inhibition of thrombin activity by SCL. The direct thrombin inhibitor argartoban was used as a positive control. We also tested the effects of $\mathrm{SCL}$ on the activity of FXa. SCL inhibited the activity of FXa (Fig. 2B). The direct FXa inhibitor rivaroxaban was used as a positive control. Therefore, Fig. 2 And B indicated that SCL exerts its anticoagulant effect by inhibiting fibrin polymerization and/or the intrinsic/extrinsic pathway.

\section{Effects of SCL on thrombin and FXa production}

Next, we determined the effects of SCL on the production of thrombin and FXa, which are the most important enzymes in the blood coagulation cascade, to define the anticoagulant mechanism of SCL. Incubation of HUVECs with SCL inhibited the production of thrombin by FVa and FXa in the presence of $\mathrm{CaCl}_{2}$ (Fig. 2C). Next, we also investigated the effects of SCL on the activation of FX by FVIla. Cells were stimulated with TNF- $\alpha$ to induce TF expression, and as shown in Fig. 2D, the rate of FX activation by FVIla was 17 -fold higher in stimulated HUVECs $(95.2 \pm 7.2 \mathrm{~nm})$ than that in non-stimulated HUVECs $(5.3 \pm 1.0 \mathrm{~nm})$. This increase in activation was abrogated by anti-TF IgG $(17.2 \pm 2.4 \mathrm{~nm})$. In addition, pre-incubation with $\mathrm{SCL}$ resulted in a dose-dependent inhibition of FX activation by FVIla (Fig. 2D). Therefore, these results suggest that SCL can inhibit the production of thrombin and FXa.

\section{Effects of SCL on the secretion of PAl-1 and t-PA protein}

TNF- $\alpha$ inhibited the fibrinolytic system in human endothelial cells by mediating the PAI-I production and disturbing the harmony between PAI-1 and t-PA, which is known to modulate coagulation and fibrinolysis $(11,12)$. In order to test the direct effects of SCL on TNF- $\alpha$-stimulated PAI- 1 secretion, cells were cultured in media with or without SCL in the absence or presence of TNF- $\alpha$ for $18 \mathrm{~h}$. Data showed that SCL treatment inhibited TNF- $\alpha$-induced PAI-1 secretion from HUVECs in a dose-dependent manner, with a significant decrease observed at concentrations of $5 \mu \mathrm{M}$ and above (Fig. 3A).

Because TNF- $\alpha$ has no significant effect on the production of t-PA (13) and the balance between plasminogen inhibitors and their activators reflects net plasminogen-activating capacity (14-16), we tested the effect of TNF- $\alpha$ with SCL on t-PA secretion from human endothelial cells. Data were consistent with those of a previous study, showing a modest decrease in the production of t-PA by TNF- $\alpha$ in HUVECs (17). This decrease was not significantly altered by treatment with SCL (Fig. 3B). Therefore, these results suggest that the PAI-1/t-PA ratio increased after TNF- $\alpha$ treatment and that SCL prevented this increase (Fig. 3C).

There are several beneficial characteristics associated with SCL use as opposed to standard pharmaceutical products, if $\mathrm{SCL}$ is developed as an anticoagulant drug. First, SCL may exhibit less side effects or toxicities. Most herbal medicines are 

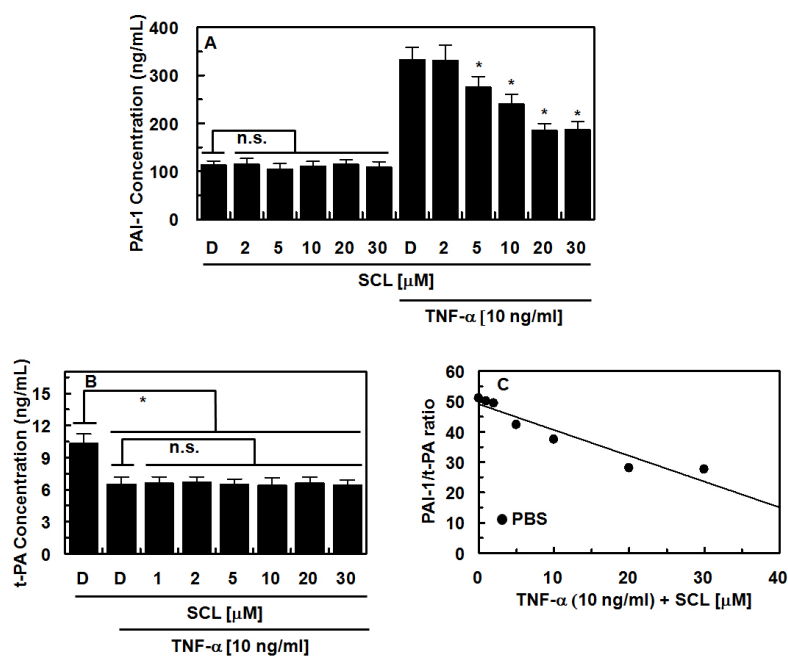

Fig. 3. Effects of $\mathrm{SCL}$ on the secretion of $\mathrm{PAl}-1$ and $\mathrm{tPA}$. (A) HUVECs were cultured with SCL in the absence or presence of TNF- $\alpha(10 \mathrm{ng} / \mathrm{mL})$ for $18 \mathrm{~h}$, and PAl-1 concentrations in culture media were determined as described in the "Materials and Methods" section. (B) HUVECs were cultured with SCL in the absence or presence of TNF- $\alpha(10 \mathrm{ng} / \mathrm{mL})$ for $18 \mathrm{~h}$, and t-PA concentrations in culture media were determined as described in the "Materials and Methods" section. (C) The PAI-1/t-PA ratio in TNF- $\alpha$-activated HUVECs from (A) and (B). D $=0.2 \%$ DMSO is the vehicle control. ${ }^{*} \mathrm{P}<0.05$ vs. TNF- $\alpha$ alone or D; n.s., not significant.

well tolerated by patients and display fewer side effects than pharmaceutical drugs (18). The second advantage of SCL use is its low cost. Herbs are inexpensive compared to prescription medications. Research, testing, and marketing considerably add to the cost of prescription medicines. Finally, the pre-clinical evaluation of the antitcoagulant potential of novel molecules requires the use of reliable and reproducible experimental models. PT, aPTT, fibrin polymerization, and platelet aggregation are the most established and commonly used preparations to determine the efficacy of novel anticoagulant drugs $(19,20)$.

As a commercial anticoagulant, heparin has been used for the prevention of venous thromboembolic diseases for more than 60 years $(21,22)$. However, many side effects of this drug have been observed, including the inability to inhibit thrombin bound to fibrin, ineffectiveness in congenital or acquired antithrombin deficiencies, development of thrombocytopenia, increased risk of thromboembolic disease when the therapeutic response is not achieved, and increased risk of bleeding when the therapeutic range is exceeded $(22,23)$. Furthermore, the amount of available heparin is low in bovine lung and pig intestine, where heparin is primarily extracted (23). Therefore, the necessity of discovering alternative anticoagulant sources has arisen with the increasing demand for safer anticoagulant therapy. Based on the current findings and advantages of herb- al medicines, SCL could replace current agents if they demonstrate successful therapeutic effects.

In conclusion, the results of this study demonstrate that $\mathrm{SCL}$ inhibited the extrinsic and intrinsic blood coagulation pathways through the inhibition of FXa and thrombin production in HUVECs. Additionally, these results show that SCL inhibited TNF- $\alpha$-induced secretion of PAI-1. These results add to previous work on the topic, and should be of interest to those designing pharmacological strategies for the treatment or prevention of vascular diseases.

\section{MATERIALS AND METHODS}

\section{Reagents}

Scolymoside was purchased from Sigma (St. Louis, MO). TNF- $\alpha$ was purchased from Abnova (Taiwan). Anti-tissue factor antibody was purchased from Santa Cruz Biologics (Santa Cruz, CA). Factor V, VII, VIla, FX, FXa, antithrombin III (AT III), prothrombin, and thrombin were obtained from Haematologic Technologies (Essex Junction, VT). aPTT assay reagent and PT reagents were purchased from Fisher Diagnostics (Middletown, Virginia), and the chromogenic substrates, S-2222 and S-2238, were purchased from Chromogenix AB (Sweden). Rivaroxaban (direct FXa inhibitor) and argatroban (direct Flla inhibitor) were purchased from Santa Cruz Inc. (Dallas, Texas). PAI-1 and t-PA ELISA kits were purchased from American Diagnostica Inc. (Stamford, CT). Other reagents were of the highest commercially available grade.

\section{Anticoagulation assay}

aPTT and PT were determined using a Thrombotimer (Behnk Elektronik, Germany), according to the manufacturer's instructions, as described previously (24-26). Citrated normal human plasma $(90 \mu \mathrm{l})$ was mixed with $10 \mu \mathrm{l}$ of scolymoside and incubated for $1 \mathrm{~min}$ at $37^{\circ} \mathrm{C}$. PT results are expressed in seconds and as International Normalized Ratios (INR), and aPTT results are expressed in seconds. INR $=$ (PT sample / PT control) ${ }^{\mid S I}$. ISI = international sensitivity index.

\section{Platelet aggregation assay}

Platelet-rich plasma (PRP) was obtained from syngeneic donor mice by double centrifugation (200 g to create platelet/plasma phase, $500 \mathrm{~g}$ to pellet platelets). The platelet-rich plasma was adjusted to a concentration of $1 \times 10^{9}$ platelets $/ \mathrm{mL}$ with use of a hemocytometer for cell counts. The platelet aggregation study was carried out according to a method previously reported $(26,27)$. Washed platelets were incubated with indicated scolymoside in TBS for $3 \mathrm{~min}$, and then stimulated by thrombin $\left(3 \mathrm{U} / \mathrm{mL}\right.$, Sigma) in $0.9 \%$ saline solution at $37^{\circ} \mathrm{C}$ for $5 \mathrm{~min}$. Platelet aggregation was recorded using an aggregometer (Chronolog, Havertown, PA).

\section{Thrombin or reptilase-catalyzed fibrin polymerization}

Thrombin-catalyzed polymerization was determined every $6 \mathrm{~s}$ 
for 20 min by monitoring turbidity at $360 \mathrm{~nm}$ using a spectrophotometer (TECAN, Switzerland) at ambient temperature. Control plasma and plasma incubated with scolymoside were diluted three times in TBS (50 mM Tris-buffered physiological saline solution $\mathrm{pH}$ 7.4) and clotted with thrombin or reptilase (final concentration - $0.5 \mathrm{U} / \mathrm{mL}$ ). The maximum polymerization rate $(V \max , \Delta \mathrm{mOD} / \mathrm{min})$ of each absorbance curve was recorded (28). All experiments were performed three times.

\section{Cell culture}

Primary human umbilical vein endothelial cells (HUVECs) were obtained from Cambrex Bio Science (Charles City, IA) and were maintained using a previously described method $(25,26,29,30)$.

\section{Animals and husbandry}

Male C57BL/6 mice (6-7 weeks old, weighing 18-20 g), purchased from Orient Bio Co. (Sungnam, Republic of Korea), were used after a 12-day acclimatization period. Animals were housed five per polycarbonate cage under controlled temperature $\left(20-25^{\circ} \mathrm{C}\right)$ and humidity $(40-45 \%)$ and a $12: 12 \mathrm{~h}$ light: dark cycle. Animals received a normal rodent pellet diet and water ad libitum during acclimatization. All animals were treated in accordance with the 'Guidelines for the Care and Use of Laboratory Animals' issued by Kyungpook National University (IRB No. KNU2012-13).

\section{Factor Xa production on the surfaces of HUVECs}

TNF- $\alpha$ (10 ng/mL for $6 \mathrm{~h}$ in serum-free medium) stimulated confluent monolayers of HUVECs (preincubated with the indicated concentrations of scolymoside for $10 \mathrm{~min}$ ) in a 96-well culture plate were incubated with FVIla $(10 \mathrm{nM})$ in buffer B (buffer A supplemented with $5 \mathrm{mg} / \mathrm{mL}$ bovine serum albumin [BSA] and $5 \mathrm{mM} \mathrm{CaCl}_{2}$ ) for $5 \mathrm{~min}$ at $37^{\circ} \mathrm{C}$ in the presence or absence of anti-TF $\operatorname{lgG}(25 \mu \mathrm{g} / \mathrm{mL})$. FX (175 $\mathrm{nM})$ was then added to the cells (final reaction mixture volume, $100 \mu \mathrm{l}$ ) and incubated for $15 \mathrm{~min}$. The reaction was stopped by addition of buffer A (10 mM HEPES, pH 7.45, $150 \mathrm{mM} \mathrm{NaCl}, 4 \mathrm{mM} \mathrm{KCl}$, and $11 \mathrm{mM}$ glucose) containing $10 \mathrm{mM}$ EDTA and the amounts of FXa generated were measured using a chromogenic substrate. Changes in absorbance at $405 \mathrm{~nm}$ over $2 \mathrm{~min}$ were monitored using a microplate reader. Initial rates of color development were converted into FXa concentrations using a standard curve prepared with known dilutions of purified human FXa.

\section{Thrombin production on the surfaces of HUVECs}

Measurement of thrombin production by HUVECs was quantitated as previously described $(31,32)$. Briefly, HUVECs were pre-incubated in $300 \mu \mathrm{l}$ containing scolymoside in $50 \mathrm{mM}$ Tris- $\mathrm{HCl}$ buffer, $100 \mathrm{pM} \mathrm{FVa}$, and $1 \mathrm{nM}$ FXa for $10 \mathrm{~min}$, followed by addition of prothrombin to a final concentration of 1 $\mu \mathrm{m}$. After $10 \mathrm{~min}$, duplicate samples $(10 \mu \mathrm{l}$ each) were transferred to a 96-well plate containing $40 \mu \mathrm{l}$ of $0.5 \mathrm{M}$ EDTA in
Tris-buffered saline per well in order to terminate prothrombin activation. Activated prothrombin was determined by measuring the rate of hydrolysis of S2238 at $405 \mathrm{~nm}$. Standard curves were prepared using amounts of purified thrombin.

\section{Thrombin activity assay}

Scolymoside in $50 \mathrm{mM}$ Tris-HCl buffer ( $\mathrm{pH}$ 7.4) containing 7.5 $\mathrm{mM}$ EDTA and $150 \mathrm{mM} \mathrm{NaCl}$ was mixed in the absence or presence of $150 \mu \mathrm{l}$ of AT III $(200 \mathrm{nM})$. Heparins with AT III (200 nM) were dissolved in physiological saline and placed in the sample wells. Following incubation at $37^{\circ} \mathrm{C}$ for $2 \mathrm{~min}$, thrombin solution $(150 \mu \mathrm{l} ; 10 \mathrm{U} / \mathrm{mL})$ was added, followed by incubation at $37^{\circ} \mathrm{C}$ for $1 \mathrm{~min}$. S-2238 (a thrombin substrate; $150 \mu \mathrm{l} ; 1.5 \mathrm{mM}$ ) solution was then added and absorbance at $405 \mathrm{~nm}$ was monitored for $120 \mathrm{~s}$ using a spectrophotometer (TECAN, Switzerland).

\section{Factor Xa (FXa) activity assay}

These assays were performed in the same manner as the thrombin activity assay, but using factor $\mathrm{Xa}(1 \mathrm{U} / \mathrm{mL})$ and S-2222 as substrates.

\section{In vivo bleeding time}

Tail bleeding times were measured using the method described previously (24-26). Briefly, C57BL/6 mice were fasted overnight before experiments. One hour after intravenous administration of scolymoside, tails of mice were transected at 2 $\mathrm{mm}$ from their tips. Bleeding time was defined as the time elapsed until bleeding stopped. When the bleeding time exceeded $15 \mathrm{~min}$, bleeding time was recorded as $15 \mathrm{~min}$ for the analysis. All animals were treated in accordance with the Guidelines for the Care and Use of Laboratory Animals issued by Kyungpook National University (IRB No. KNU2012-13).

\section{Ex vivo clotting time}

Male C57BL/6 mice were fasted overnight and scolymoside in $0.5 \%$ DMSO was administered by intravenous injection. One hour after administration, arterial blood samples $(0.1 \mathrm{~mL})$ were withdrawn into $3.8 \%$ Na-citrate $(1 / 10 ; \mathrm{v} / \mathrm{v})$ for ex vivo aPTT and PT determination.

\section{ACKNOWLEDGEMENTS}

This study was supported by the National Research Foundation of Korea (NRF) funded by the Korean government [MSIP] (Grant No. 2012R1A5A2A42671316) and by a grant (PJ010840) from the Agenda program, Rural Development Administration.

\section{REFERENCES}

1. Prior RL and Cao G (1999) Antioxidant capacity and polyphenolic components of teas: implications for altering in vivo antioxidant status. Proc Soc Exp Biol Med 220, 255-261 
2. Warren CP (1999) Antioxidant effects of herbs. Lancet 353, 676

3. Joubert E, Joubert ME, Bester C, De Beer D and De Lange JH (2011) Honeybush (Cyclopia spp.): From local cottage industry to global markets - The catalytic and supporting role of research. S A J Bot 77, 889-907

4. Sanchez GM, Re L, Giuliani A, Nunez-Selles AJ, Davison GP and Leon-Fernandez OS (2000) Protective effects of Mangifera indica L. extract, mangiferin and selected antioxidants against TPA-induced biomolecules oxidation and peritoneal macrophage activation in mice. Pharmacol Res 42, 565-573

5. Leiro JM, Alvarez E, Arranz JA, Siso IG and Orallo F (2003) In vitro effects of mangiferin on superoxide concentrations and expression of the inducible nitric oxide synthase, tumour necrosis factor-alpha and transforming growth factor-beta genes. Biochem Pharmacol 65, 1361-1371

6. Pardo Andreu GL, Maurmann N, Reolon GK et al (2010) Mangiferin, a naturally occurring glucoxilxanthone improves long-term object recognition memory in rats. Eur J Pharmacol 635, 124-128

7. Kazuno S, Yanagida M, Shindo N and Murayama K (2005) Mass spectrometric identification and quantification of glycosyl flavonoids, including dihydrochalcones with neutral loss scan mode. Anal Biochem 347, 182-192

8. Palomo I, Fuentes E, Padro T and Badimon L (2012) Platelets and atherogenesis: Platelet anti-aggregation activity and endothelial protection from tomatoes (Solanum lycopersicum L.). Exp Ther Med 3, 577-584

9. Roberfroid MB (2007) Inulin-type fructans: functional food ingredients. J Nutr 137, 2493S-2502S

10. Hasler CM, Kundrat S and Wool D (2000) Functional foods and cardiovascular disease. Curr Atheroscler Rep 2, 467-475

11. Philip-Joet F, Alessi MC, Philip-Joet C et al (1995) Fibrinolytic and inflammatory processes in pleural effusions. Eur Respir J 8, 1352-1356

12. Schleef RR, Bevilacqua MP, Sawdey M, Gimbrone MA Jr and Loskutoff DJ (1988) Cytokine activation of vascular endothelium. Effects on tissue-type plasminogen activator and type 1 plasminogen activator inhibitor. J Biol Chem 263, 5797-5803

13. Hamaguchi E, Takamura T, Shimizu A and Nagai Y (2003) Tumor necrosis factor-alpha and troglitazone regulate plasminogen activator inhibitor type 1 production through extracellular signal-regulated kinase- and nuclear factor-kappaB-dependent pathways in cultured human umbilical vein endothelial cells. J Pharmacol Exp Ther 307, 987-994

14. Davie EW (1995) Biochemical and molecular aspects of the coagulation cascade. Thromb Haemost 74, 1-6

15. Davie EW, Fujikawa K and Kisiel W (1991) The coagulation cascade: initiation, maintenance, and regulation. Biochemistry 30, 10363-10370

16. Quinn C, Hill J and Hassouna H (2000) A guide for diagnosis of patients with arterial and venous thrombosis. Clin Lab Sci 13, 229-238

17. Lopez S, Peiretti F, Bonardo B, Juhan-Vague I and
Nalbone G (2000) Effect of atorvastatin and fluvastatin on the expression of plasminogen activator inhibitor type- 1 in cultured human endothelial cells. Atherosclerosis 152, 359-366

18. Lee KH (2000) Research and future trends in the pharmaceutical development of medicinal herbs from Chinese medicine. Public Health Nutr 3, 515-522

19. Despotis GJ, Gravlee G, Filos K and Levy J (1999) Anticoagulation monitoring during cardiac surgery: a review of current and emerging techniques. Anesthesiology 91, 1122-1151

20. Jauch EC, Saver JL, Adams HP Jr et al (2013) Guidelines for the early management of patients with acute ischemic stroke: a guideline for healthcare professionals from the American Heart Association/American Stroke Association. Stroke 44, 870-947

21. Wells PS, Forgie MA and Rodger MA (2014) Treatment of venous thromboembolism. JAMA 311, 717-728

22. Hirsh J, Raschke R, Warkentin TE, Dalen JE, Deykin D and Poller L (1995) Heparin: mechanism of action, pharmacokinetics, dosing considerations, monitoring, efficacy, and safety. Chest 108, 258S-275S

23. Pereira MS, Melo FR and Mourao PA (2002) Is there a correlation between structure and anticoagulant action of sulfated galactans and sulfated fucans? Glycobiology 12, 573-580

24. Lee W, Yoo H, Ku SK, Kim JA and Bae JS (2013) Anticoagulant activities of piperlonguminine in vitro and in vivo. BMB Rep 46, 484-489

25. Ku SK and Bae JS (2014) Antiplatelet and antithrombotic activities of purpurogallin in vitro and in vivo. BMB Rep 47, 376-381

26. Ku SK and Bae JS (2014) Antithrombotic activities of sulforaphane via inhibiting platelet aggregation and Flla/FXa. Arch Pharm Res 37, 1454-1463

27. Kim SY, Kim S, Kim JM et al (2011) PKC inhibitors RO 31-8220 and Go 6983 enhance epinephrine-induced platelet aggregation in catecholamine hypo-responsive platelets by enhancing Akt phosphorylation. BMB Rep 44, 140-145

28. Nowak P, Zbikowska HM, Ponczek M, Kolodziejczyk J and Wachowicz B (2007) Different vulnerability of fibrinogen subunits to oxidative/nitrative modifications induced by peroxynitrite: functional consequences. Thromb Res 121, 163-174

29. Bae JS, Lee W, Nam JO, Kim JE, Kim SW and Kim IS (2014) Transforming Growth Factor beta-induced Protein Promotes Severe Vascular Inflammatory Responses. Am J Respir Crit Care Med 189, 779-786

30. Ku SK, Han MS, Lee MY, Lee YM and Bae JS (2014) Inhibitory effects of oroxylin A on endothelial protein $C$ receptor shedding in vitro and in vivo. BMB Rep 47, 336-341

31. Bae JS (2011) Antithrombotic and profibrinolytic activities of phloroglucinol. Food Chem Toxicol 49, 1572-1577

32. Kim TH, Ku SK and Bae JS (2012) Antithrombotic and profibrinolytic activities of eckol and dieckol. J Cell Biochem $113,2877-2883$ 